\title{
ANALISIS KONTRIBUSI PAJAK HOTEL DAN PAJAK RESTORAN UNTUK MENINGKATKAN PENDAPATAN ASLI DAERAH (PAD) DI KABUPATEN KOLAKA
}

\author{
Oleh \\ Ika Maya Sari ${ }^{1}$, Intihanah ${ }^{2}$, Septi Marnianti Putri ${ }^{3}$ \\ Jurusan Akuntansi Fakultas Ekonomi dan Bisnis Universitas Halu Oleo Kendari \\ Sulawesi Tenggara
}

\begin{abstract}
ABSTRAK
Penelitian ini bertujuan untuk mengetahui dan menjelaskan besarnya kontribusi dan efektivitas Pajak Hotel Melati dan Pajak Restoran Untuk Meningkatkan Pendapatan Asli Daerah di Kabupaten Kolaka. Manfaat dari penelitian yaitu agar memberikan informasi tentang beesarnya kontribusi dan tingkat efektvitas Pajak Hotel Melati dan Pajak Restoran Untuk Meningkatkan Pendapatan Asli Daerah di Kabupaten Kolaka. Penelitian ini menggunakan metode analisis deskriptif. Teknik pengumpulan data yaitu wawancara dan dokumentasi berupa data target dan realisasi kontribusi dan tingkat efektivitas Pajak Hotel Melati dan Pajak restoran.

Hasil Penelitian menunjukkan bahwa kontribusi Pajak Hotel Melati dan Pajak Restoran untuk meningkatkan Pendapatan Asli Daerah di Kabupaten Kolaka yaitu sangat kurang dengan persentase masih dibawah 10\%. Demikian juga efektivitas Pajak Hotel Melati pada tahun 2017 dan 2018 dibawah 100\% tergolong kriteria belum efektif tetapi pada tahun 2019 meningkat diatas 100\% sehingga tergolong kriteria sangat efektif. Berbanding terbalik dengan efektivitas Pajak Restoran pada tahun 2017 sebesar 84,98\% tergolong kriteria cukup efektif dan ditahun 2018 sebesar 93,37 tergolong kriteria efektif, kemudian terjadi peningkatan di tahun 2019 sebesar 118,02\% tergolong kriteria sangat efektif.
\end{abstract}

Kata Kunci: Kontribusi, Efektivitas, PAD, Pajak Hotel Melati dan Pajak Restoran

\section{ABSTRACT}

This research aims to find out and explain the amount of contribution and effectiveness of jasmine hotel tax and restaurant tax to increase the Local Indigeneous Income in Kolaka Regency. The benefits of this study are to provide information about the amount of contribution and effectiveness of jasmine hotel tax and restaurant tax to increase the Local Indegeneous Income in Kolaka Regency. The research uses descriptive methods. Data collection techniques namely interviews and documentation in the form of target data and the realization of contributions and effectiveness of jasmine hotel tax and restaurant tax.

The result showed that the contribution of jasmine hotel tax to increase the Local Indigenous Income in Kolaka Regency is very less with the percentage still below $10 \%$. Likewise, the effectiveness of jasmine hotel tax in 2017 and 2018 was still below 100\% classified as ineffective criteria but in 2019 increased above 100\% classified as very effective criteria. Inversely proportional to the effectiveness of restaurant tax in 2017 amounting to 84,98\% which is classified as quite effective criteria and in 2018 as much as 93,37\% is classified as effective criteria, then there is an crease in 2019 of 118,02\% which is classified as very effective criteria.

Keywords: Contribution, Effectiveness, Local Indegeneous Income, Jasmine Hotel Tax, Restaurant Tax 


\section{PENDAHULUAN}

Indonesia merupakan negara kesatuan yang menganut asas otonomi daerah. Sebagai negara kepulauan yang memiliki wilayah yang luas, dalam penyelenggaraan pemerintahannya Indonesia dibagi atas daerah-daerah dan setiap daerah tersebut mempunyai hak dan kewajiban. Hak dan kewajiban daerah adalah untuk mengatur sendiri urusan pemerintahannya agar dapat meningkatkan efisiensi dan efektifitas penyelenggaraan pemerintahan dan pelayanan kepada masyarakat, sebagaimana diatur dalam UndangUndang Nomor 23 Tahun 2014. Otonomi daerah merupakan tujuan pemerintah pusat untuk mewujudkan pembangunan yang merata disetiap daerah. Dengan adanya otonomi daerah, daerah dipacu untuk dapat berkreasi dalam mencari sumber penerimaan dana yang sesuai dengan kondisi dan potensi masing-masing daerah untuk dapat meningkatkan Pendapatan Asli Daerah (PAD) yang digunakan untuk mendukung pembiayaan pengeluaran pemerintah daerah dalam rangka penyelenggarakan pemerintah dan pembangunan (Memah, 2013).

Pendapatan Asli Daerah berfokus pada dua aspek utama, yaitu pajak dan retribusi, meskipun masih ada aspek penerimaan resmi lain yang termasuk dalam Pendapatan Asli Daerah (PAD). Salah satu upaya untuk meningkatkan penerimaan daerah yaitu dengan mengoptimalkan potensi dalam sektor pariwisata. Keterkaitan industri pariwisata dengan penerimaan daerah berjalan melalui jalur PAD dan Bagi Hasil Pajak/Bukan Pajak.

Hotel adalah bangunan yang dipakai orang untuk menginap dan dipungut bayaran. Hal ini didukung oleh (Undang-Undang Nomor 28 Tahun 2009) yang menyatakan bahwa hotel adalah fasilitas penyedia jasa penginapan/peristirahatan termasuk jasa terkait lainnya dengan dipungut bayaran yang mencakup gubuk pariwisata rumah penginapan dan sejenisnya serta rumah kos yang memiliki kamar lebih dari 10 (sepuluh). Sehingga pajak hotel merupakan pajak atas pelayanan yang disediakan oleh hotel yang mempengaruhi Pendapatan Asli Daerah (PAD).

Restoran dalah fasilitas penyedia makanan atau minuman dengan dipungut bayaran yang mencakup juga rumah makan, kafetarian, warung dan kantin. Pajak restoran/rumah makan yang mempengaruhi pendapatan daerah setempat (Undang-Undang Nomor 28 Tahun 2009).

Pemerintah Kabupaten Kolaka dalam usahanya mengembangkan dan membangun daerahnya telah berupaya untuk meningkatkan sumber-sumber pendapatan asli daerahnya sesuai potensi yang dimilikinya. Upaya tersebut dilakukan dengan intensifikasi sumbersumber pendapatan asli daerah agar peningkatan target tiap tahunnya dapat diikuti dengan pencapaian realisasi secara konsisten.

Pada tahun 2015 Badan Pendapatan Daerah (Bapenda) mendata beberapa objek pajak termasuk hotel dan restoran yang terdapat di Kabupaten Kolaka. Berikut adalah data yang diperoleh dari Badan Pendapatan Daerah Kabupaten Kolaka mengenai jumlah Hotel di Kabupaten Kolaka pada tahun 2017-2019, sebagaimana dipaparkan pada Tabel 1.1

\section{Tabel 1.1}

Jumlah Hotel dan Restoran di Kabupaten Kolaka

Tahun 2017-2019

\begin{tabular}{|l|l|l|l|}
\hline Tahun & Hotel & \multirow{2}{*}{ Restoran } \\
\hline \multirow{2}{*}{ Jumlah } & Bintang 3 & Melati & \\
\cline { 2 - 4 } & 1 & 27 & 7 \\
\hline & 28 & 7 \\
\hline
\end{tabular}

Sumber: Badan Pendapatan Daerah Kabupten Kolaka 
Jurnal Akuntansi dan Keuangan (JAK)

Volume 6, No. 1 Februari Tahun 2021

Page: 182 - 191

http://ojs.uho.ac.id/index.php/iak-uho/issue/archive

e-ISSN: 2088-4656

Berdasarkan Tabel 1.1. menunjukkan bahwa di Kabupaten Kolaka hotel bintang 3 sebanyak 1dan hotel melati sebanyak 27. Sedangkan untuk restoran hanya sebanyak 5.

Berikut adalah data yang diperoleh dari Badan Pendapatan Daerah Kabupaten Kolaka mengenai Target dan Realisasi Pajak Hotel dan Restoran Tahun 2016-2018.

Tabel 1.2

Target dan Realisasi Penerimaan Pajak Hotel di Kabupten Kolaka

Tahun 2017-2019

\begin{tabular}{|c|c|c|c|c|}
\hline \multirow[t]{2}{*}{ Tahun } & \multicolumn{2}{|l|}{ Target } & \multicolumn{2}{|l|}{ Realisasi } \\
\hline & Bintang 3 & Melati & Bintang 3 & Melati \\
\hline 2017 & 650.000 .000 & 76.052 .400 & 496.415 .656 & 47.697 .000 \\
\hline 2018 & 650.000 .000 & 76.052 .400 & 584.331 .339 & 36.909 .300 \\
\hline 2019 & 650.000 .000 & 76.052 .400 & 751.799 .681 & 98.101 .746 \\
\hline
\end{tabular}

Sumber: Badan Pendapatan Daerah Kabupten Kolaka

Tabel 1.2. keseluruhan dapat dilihat bahwa realisasi peneriman pajak Hotel Bintang 3 dari tahun 2017 sampai dengan tahun 2019 meningkat setiap tahunnya. Sedangkan penerimaan pajak Hotel Melati pada tahun 2017 sampai dengan tahun 2019 mengalami fluktuasi setiap tahunnya.

Tabel 1.3

Terget Dan Realisasi Penerimaan Pajak Restoran di Kabupaten Kolaka Tahun 2017-2019

\begin{tabular}{|l|l|l|}
\hline Tahun & Target & Realisasi \\
\hline 2017 & 700.000 .000 & 594.892 .010 \\
\hline 2018 & 850.000 .000 & 793.660 .380 \\
\hline 2019 & 850.000 .000 & 1.003 .173 .466 \\
\hline
\end{tabular}

Sumber: Badan Pendapatan Daerah Kabupten Kolaka

Dilihat dari tabel 1.3. secara keseluruhan bahwa realisasi penerimaan pajak Restoran dari tahun 2017 sampai dengan tahun 2019 mengalami mengalami peningkatan setiap tahunnya. Berikut adalah data Target dan Realisasi Penerimaan PAD Kabupaten Kolaka Tahun 2017-2019 yang diperoleh dari Badan Pendapatan Daerah Kabupaten Kolaka.

\section{Tabel 1.4}

Target dan Realisasi Penerimaan Pendapatan Asli Daerah (PAD) Kabupaten Kolaka Tahun 2017-2019

\begin{tabular}{|l|l|l|}
\hline Tahun & Target & Realisasi \\
\hline 2017 & 20.697 .740 .300 & 23.107 .672 .606 \\
\hline 2018 & 25.844 .440 .300 & 28.138 .141 .187 \\
\hline 2019 & 29.800 .000 .000 & 37.400 .000 .000 \\
\hline
\end{tabular}

Sumber: Badan Pendapatan Daerah Kabupten Kolaka

Berdasarkan Tabel 1.4 dapat dilihat realisasi Pendapatan Asli Daerah (PAD) mengalami peningkatan setiap tahunnya. Dengan meningkatnya jumlah PAD tersebut pemerintah Kabupaten Kolaka terus mengembangkan pembangunan daerah dan fasilitas yang terdapat di Kabupaten Kolaka dan menargetkan untuk melakukan pemungutan pajak yang efektif dan efisien guna pencapaian tujuan pembangunan daerah.

\section{Pajak}

\section{TINJAUAN PUSTAKA}

Pajak adalah iuran kepada Negara (yang dapat dipaksakan) dan wajib membayarnya menurut Peraturan-Peraturan Umum (Undang-Undang) dengan tidak mendapat iterprestasi kembali dan digunakan untuk membiayai pengeluaran-pengeluaran umum yang 
Jurnal Akuntansi dan Keuangan (JAK)

Volume 6, No. 1 Februari Tahun 2021

Page: 182 - 191

http://ojs.uho.ac.id/index.php/iak-uho/issue/archive

e-ISSN: 2088-4656

berhubungan dengan tugas negara yang menyelenggarakan pemerintahan. (Sumarsan, 2010: 4)

Dari definisi diatas dapat di simpulkan bahwa pajak memiliki beberapa unsur pokok yaitu:

1. Pajak dipungut oleh negara baik pemerintah pusat maupun pemrrintah daerah berdasarkan Undang-Undang serta aturan pelaksanaannya.

2. Pungutan pajak mengisyaratkan adanya alih dana (sumber daya) dari sector swasta ke sektor negara.

3. Pungutan pajak diperuntukkan bagi keperluan pembiayaan umum pemerintah dalam rangka menjalankan fungsi pemerintahan, baik rutin maupun pembangunan.

4. Tidak ditunjukkan adanya imbalan (kontraprestasi) individual oleh pemrintah terhadap pembayaran pajak yang dilakukan oleh para wajib pajak.

5. Selain fungsi sebgai anggaran, pajak juga berfungsi sebagai alat untuk mengatur untuk melaksanakan kebijakan negara dibidang sosiall dan ekonomi.

\section{Pajak Daerah}

Undang-Undang Nomor 28 tentang Pajak Daerah dan Retribusi Daerah pasal 1, pajak daerah adalah kontribusi pajak wajib kepada daerah yang terutang oleh orang pribadi atau badan yang bersifat memaksa berdasarkan Undang-Undang, dengan tidak mendapatkan imbalan secara langsung dan gunakan untuk keperluan daerah bagi sebesarbesarnya kemakmuran rakyat.

Pajak daerah merupakan wewenang daerah yang diatur dalam Undang-Undang tentang pokok-pokokpemerintah daerah dan hasilnya digunakan untuk pembiayaan rumah tangga daerah itu sendiri.

Undang-Undang Nomor 28 Tahun 2009 Pasal 2 tentang pajak daerah dan retribusi daerah terdapat 5 jenis pajak provinsi dan 11 jenis pajak kabupaten/kota.

1. Secara rinci provinsi terdiri dari:

a. Pajak kendaraan bermotor

b. Pajak bea balik nama kendaraan bermotor

c. Pajak bahan bakar kendaraan bermotor

d. Pajak air permukaan

e. Pajak rokok

2. Pajak Kabupaten/Kota terdiri dari:

a. Pajak hotel

b. Pajak restoran

c. Pajak hiburan

d. Pajak reklame

e. Pajak penerangan jalan

f. Pajak parkir

g. Pajak air tanah

h. Pajak sarang burung wallet

i. Pajak bumi bangunan perdesaan dan perkotaan

\section{Pajak Hotel}

$$
\text { j. Bea perolehan hak atas tanah dan bangunan }
$$

Undang-Undang Nomor 28 Tahun 2009 Pasal 1, pajak hotel adalah pajak atas pelayanan yang disediakan oleh hotel. Pengertian hotel menurut Marihot (2010: 304) adalah fasilitas penyediajasa penginapan/peristirahatan termasuk jasa terkait lainnya dengan dipungut bayaran, yang mencakup juga motel, losmen, gubunk pariwisata, wisma pariwisata, wisma pariwisata, pesanggarahan, rumah penganapan dan sejenisnya serta rumah kos yang jumlah kamar lebih daeri 10 kamar. 
Objek pajak hotel adalah pelayanan yang disediakan oleh hotel dengan pembayaraan, termasuk jasa penunjang sebgai kelengkapan hotel yang sifatnya memberikan kemudahan dan kenyamanan termasuk fasilitas olahraga dan hiburan. Subjek pajak hotel adalah orang pribadi atau badan yang melakukan pembayaran kepada orang pribadi atau badan yang mengusahakan hotel. Wajib pajak hotel adalah orang pribadi atau badan yang mengusahakan hotel. Tarif pajak hotel ditetapkan paling tinggi sebesar $10 \%$.

\section{Pajak Restoran}

Pajak restoran adalah fasilitas penyedia makanan dan atau minuman dengan dipungut bayaran, yang mencakup juga rumah makan, kafetaria,kantin, warung, bar dan sejenisnya termasuk jasa boga/catering (Marihot, 2010: 330). Sesuai dengan UndangUndang Nomor 28 Tahun 2009 Pasal 1 angka 22 dan 23, pajak restoran adalah pajak atas pelayanan yang disediakan oleh restoran. Menurut Undang-Undang Republik Indonesia Nomor 28 Tahun 2009 tentang Pajak Daerah dan Retribusi Daerah.

Objek pajak restoran adalah pelayanan yang disediakan oleh restoran. Pelayanan yang disediakan oleh restoran sebagaimana dimaksud pada ayat (1) meliputi pelayan penjualan makannan dan atau minuman yang dikonsumsi oleh pembeli, baik yang dikonsumsi di tempat pelayanan maupun ditempat lain. Subjek pajak restoran adalah orang pribadi atau badan yang membeli makanan atau minuman dari restoran. Wajib pajak restoran adalah orang pribadi atau badan yang mengusahakan restoran. Tarif pajak restoran ditetapkan paling tinggi $10 \%$.

\section{Pendapatan Asli Daerah}

Menurut Halim (2007: 96) pendapatan asli daerah adalah semua penerimaan daerah yang berasal daeri sumber ekonomi asli daerah berupa pajak daerah, retribusi daerah, hasil penggolongan kekayaan daerahyang dipisahkan dan lain-lain pada PAD yang sah. Jadi pengertian daeri pendapatan asli daerah dapat dikatakan sebagai pendapatan rutin dari usaha-usaha pemerintah daerah dalam memanfaatkan potensi-potensi sujmber keuangan daerah untuk membiayai tuagas dan tanggungjawab sebagaimana yang dimaksud dalam Undang-Undang Nomor 33 Tahun 2004 tentang Perimbangan Keuangan antara Pemerintah Pudsat dan Daerah.

\section{METODE PENELITIAN}

Penelitian ini dilakukan di Badan Pendapatan Daerah Kabupaten Kolaka, yang bertempat di Jalan Khairil Anwar, Kelurahan Lamokato, Kecamatan Kolaka, Kabupaten Kolaka, Provinsi Sulawesi Tenggara. Objek penelitian ini adalah "Analisis Kontribusi Pajak Hotel dan Pajak Restoran Untuk Meningkatkan Pendapatan Asli Daerah di Kabupaten Kolaka". Jenis data yang digunakan dalam penelitian ini adalah data kuantitatif dan data kualitatif. Data kuantitatif dalam penelitian ini adalah Laporan Realisasi Penerimaan Pajak Daerah Tahun 2017-2019, Laporan Pajak Hotel Melati dan Restoran. Data kualitatif dalam penelitian ini yaitu hasil wawancara langsung dari pihak terkat pemungut pajak hotel dan pajak restoran di Badan Pendapatan Daerah Kabupaten Kolaka dan berupa data tentang Peraturan Pemerintah Daerah mengenai pajak hotel dan pajak restoran.

Sumber data yang digunakan dalam penelitian ini menggunakan data primer dan sekunder. Data primer yaitu melakukan wawancara secara langsung kepada pihak-pihak terkait di BAPENDA Kabupaten Kolaka. Sedangkan data sekunder yaitu berupa dokumen data realisasi penerimaan pajak hotel melati, restoran dan PAD di BAPENDA Kabupaten Kolaka. Teknik pengumpulan data dalam penelitian ini adalah dokumentasi dan interview. Dokumentasi dalam penelitian ini adalah pengumpulan data yang berupa target dan realisasi $\mathrm{PAD}$, pajak hotel melati dan pajak restoran. Interview dalam penelitian ini yaitu wawancara 
Jurnal Akuntansi dan Keuangan (JAK)

Volume 6, No. 1 Februari Tahun 2021

Page: 182 - 191

http://ojs.uho.ac.id/index.php/jak-uho/issue/archive

e-ISSN: 2088-4656

secara langsung pegawai pada bagian sekretaris BAPENDA Bapak Laode Popo dan Ibu Titin yang terkait dengan masalah yang akan di bahas dalam penelitian ini.

Metode analisis data yang digunakan dalam penelitian ini yaitu analisis kontribusi dan analisis efektivitas. Analisis kontribusi yaitu suatu alat yang digunakan untuk mengetahui seberapa besar kontribusi atau sumbangan dari penerimaan pajak hotel melati dan pajak restoran terhadap peningkatan PAD di Kabupaten Kolaka.

\section{HASIL DAN PEMBAHASAN}

\section{Hasil Penelitian}

1. Analisis Kontribusi Pajak Hotel Melati dan Pajak Restoran Terhadap Pendapatan Asli Daerah (PAD) Kabupaten Kolaka

Rasio kontribusi digunakan untuk mengetahui tingkat kontribusi pajak hotel melati atau pajak restoran pada Pendapatan Asli Daerah (PAD). Cara perhitungannya yaitu dengan membandingkan realisasi penerimaan pajak hotel melati atau pajak restoran dengan pendapatan asli daerah yang lebih jelasnya dapat dilihat sebagai berikut:

Kontribusi $=\frac{\text { Realisasi Penerimaan Pajak Hotel atau Pajak Restoran }}{\text { Penerimaan Pendapatan Asli Daerah }} \times 100 \%$

\section{Kontribusi Pajak Hotel Melati Terhadap Pendapatan Asli Daerah}

Kabupaten Kolaka Tahun 2017-2019

\begin{tabular}{|l|l|l|l|l|}
\hline Tahun & $\begin{array}{l}\text { Penerimaan } \\
\text { Pajak Hotel Melati }\end{array}$ & $\begin{array}{l}\text { Pendapatan Asli } \\
\text { Daerah }\end{array}$ & $\begin{array}{l}\text { Kontribusi } \\
(\boldsymbol{\%})\end{array}$ & Kriteria \\
\hline 2017 & 47.697 .000 & 23.107 .672 .606 & 0,20 & Sangat Kurang \\
\hline 2018 & 36.909 .300 & 28.138 .141 .187 & 0,13 & Sangat Kurang \\
\hline 2019 & 98.101 .746 & 37.400 .000 .000 & 0,26 & Sangat Kurang \\
\hline
\end{tabular}

Sumber: Data diolah tahun 2020

Dari perhitungan tabel diatas dapat dilihat bahwa kontribusi pajak hotel terhadap PAD Kabupaten Kolaka pada tahun 2017 hingga tahun 2019 mengalami fluktuasi setiap tahunnya. Tahun 2017 kontribusi pajak hotel terhadap PAD Kabupaten Kolaka berada di angka 0,20\%, ditahun 2018 menurun di angka 0,13\% dan tahun 2019 meningkat di angka $0,26 \%$.

Kontribusi Pajak Restoran Terhadap Pendapatan Asli Daerah Kabupaten Kolaka Tahun 2017-2019

\begin{tabular}{|l|l|l|l|l|}
\hline Tahun & $\begin{array}{l}\text { Penerimaan } \\
\text { Pajak Restoran }\end{array}$ & $\begin{array}{l}\text { Pendapatan Asli } \\
\text { Daerah }\end{array}$ & $\begin{array}{l}\text { Kontribus } \\
\mathbf{i} \\
(\%)\end{array}$ & Kriteria \\
\hline 2017 & 594.892 .010 & 23.107 .672 .606 & 0,25 & Sangat Kurang \\
\hline 2018 & 793.660 .380 & 28.138 .141 .187 & 2,82 & Sangat Kurang \\
\hline 2019 & 1.003 .173 .466 & 37.400 .000 .000 & 2,68 & Sangat Kurang \\
\hline
\end{tabular}

Sumber: Data diolah tahun 2020

Dari perhitungan tabel diatas dapat dilihat bahwa kontribusi pajak restoran terhadap PAD Kabupaten Kolaka pada tahun 2017 hingga tahun 2019 mengalami fluktuasi setiap tahunnya. Tahun 2017 kontribusi pajak restoran terhadap PAD Kabupaten Kolaka berada di angka 0,25\%, ditahun 2018 meningkat di angka 2,82\% dan tahun 2019 menurun di angka $2,68 \%$.

2. Analisis Efektivitas Pajak Hotel Melati dan Pajak Restoran Kabupaten Kolaka

Pajak hotel dan pajak restoran memiliki potensi yang sangat besar untuk meningkatkan Pendapatan Asli Daerah sehingga perlu dimaksimalkan penerimaan 
pajaknya. Rasio tingkat efektivitas digunakan untuk mengukur kinerja dalam mobilisasi penerimaan pajak hotel melati dan pajak restoran efektif atau tidak maka menggunakan dua komponen meliputi target penerimaan pajak hotel atau pajak restoran dan realisasi pajak hotel atau pajak restoran.

Efektivitas pajak hotel dan pajak restoran dapat diketahui dengan cara membandingkan realisasi penerimaan pajak hotel atau pajak restoran dengan target penerimaan pajak hotel atau pajak restoran yang lebih jelasnya dapat dilihat sebagai berikut: Efektivitas $=\frac{\text { Realisasi Penerimaan Pajak Hotel atau Pajak Restoran }}{\text { Target Pajak Hotel dan Pajak }} \times 100$

\section{Efektivitas Pajak Hotel Melati Kabupaten Kolaka}

Tahun 2017-2019

\begin{tabular}{|c|c|c|c|c|}
\hline \multirow{2}{*}{ Tahun } & \multicolumn{2}{|c|}{ Pajak Hotel Melati } & \multirow{2}{*}{$\begin{array}{l}\text { Efektivitas } \\
(\%)\end{array}$} & \multirow{2}{*}{ Kriteria } \\
\hline & Target & Realisasi & & \\
\hline 2017 & 76.052 .400 & 47.697 .000 & 62,71 & Kurang Efektif \\
\hline 2018 & 76.052 .400 & 36.909 .300 & 48,53 & Tidak Efektif \\
\hline 2019 & 76.052 .400 & 98.101 .746 & 128,99 & Sangat Efektif \\
\hline
\end{tabular}

Sumber: Data diolah tahun 2020

Pada tabel diatas menunjukkan pencapaian efektivitas Badan Pendapatan Daerah Kabupaten Kolaka dari tahun 2017 sampai dengan 2019 mengalami fluktuasi setiap tahunnya. Pencapaian terendah berada ditahun 2018 dengan persentasi 48,53\% tergolong tidak efektif dan pencapaian tertinggi berada di tahun 2019 dengan persentasi 128,99\% yang tergolong sangat efektif.

\section{Efektivitas Pajak Restoran Kabupaten Kolaka}

Tahun 2016-2018

\begin{tabular}{|l|l|l|l|l|}
\hline \multirow{2}{*}{ Tahun } & \multicolumn{2}{|l|}{ Pajak Restoran } & Efektivitas & \multirow{2}{*}{ Kriteria } \\
\cline { 2 - 3 } & Target & Realisasi & 84,98 & Cukup Efektif \\
\hline 2017 & 700.000 .000 & 594.892 .010 & 93,37 & Efektif \\
\hline 2018 & 850.000 .000 & 793.660 .380 & $9602 \%$ & Sangat Efektif \\
\hline 2019 & 850.000 .000 & 1.003 .173 .466 & $118,02 \%$ & \\
\hline
\end{tabular}

Sumber: Data diolah tahun 2020

Pada tabel diatas menunjukkan bahwa pencapaian efektivitas Badan Pendapatan Daerah Kabupaten Kolaka tahun 2017 sampai dengan 2019 meningkat setiap tahunnya. Pencapaian terendah berada di tahun 2017 dengan persentase 84,98\% tergolong cukup efektif dan tertinggi berada di tahun 2019 dengan persentase 118,02\% tergolong sangat efektif.

\section{Pembahasan}

\section{Kontribusi Pajak Hotel Melati dan Pajak Restoran Terhadap Pendapatan Asli Daerah (PAD) Kabupaten Kolaka}

Berdasarkan penelitian yang dilakukan, kontribusi pajak hotel melati terhadap Pendapatan Asli Daerah Kabupaten Kolaka ternyata berfluktuasi setiap tahunnya begitu pula dengan realisasi penerimaan pajak hotel melati berfluktuasi setiap tahunnya. Jika dilihat dari keseluruhan, kontribusi pajak hotel melati terhadap peningkatan Pendapatan Asli Daerah $<10 \%$ termasuk dalam kategori sangat kurang. Dikarenakan pada tahun 2017 masih ada wajib pajak yang belum menyelesaikan atau menunda kewajibannya sehingga mengurangi jumlah realisasi penerimaan pajak. Begitu juga di tahun 2018 dikarenakan ada waib pajak yang tidak melaporkan omzet yang sebenarnya. Kemudian terjadi peningkatan di tahun 2019 dikarenakan mulai diberlakukan pemasangan alat tapping box. Meskipun terjadi peningkatan di realisasi penerimaan pajak hotel melati dan kontribusi pajak hotel 
melati terhadap PAD tetapi masih tergolong. Hal ini dikarena adanya penerimaan yang lain yang lebih besar kontribusinya terhadap PAD.

Sedangkan berdasarkan penelitian yang dilakukan, kontribusi pajak restoran terhadap Pendapatan Asli Daerah Kabupaten Kolaka mengalami fluktuasi setiap tahunnya. Hal ini berbanding terbalik dengan realisasi penerimaan pajak restoran yang meningkat setiap tahunnya. Jika dilihat dari keseluruhan kontribusi pajak restoran terhadap PAD $<10 \%$ masih tergolong kriteria sangat kurang. Dikarenakan pada tahun 2017 kurangnya pengadaan kegiatan dan event di Kabupaten Kolaka yang bias menarik perhatian. Kemudian pada tahun 2018 terjadi peningkatan dikarenakan adanya kegiatan Pekan Olahraga Daerah (PORDA) yang dilaksanakan di Kabupaten Kolaka Utara yang menyebabkan orang yang berada diluar daerah yang melintasi Kabupaten Kolaka menyempatkan makan di restoran yang ada di Kabupaten Kolaka. Pada tahun 2019 kontribusi pajak restoran terhadap PAD mengalami penurunan, meskipun telah dilakukan pemasangan alat tapping box dan realisasi penerimaan pajak restoran yang melebihi target yang ditetapkan akan tetapi terjadi kenaikan yang cukup signifikan dari jumlah realisasi Pendapatan Asli Daerah menjadi salah satu penyebabnya.

Berdasarkan keterangan dari Bapak Laode Popi pada selaku Sekretaris Badan Pendapatan Daerah kabupaten Kolaka pada hari Jumat, 17 Juli 2020 hal ini disebabkan oleh adanya hambatan yang dihadapi pemerintah Kabupaten Kolaka dalam meningkatkan pajak restorannya diantaranya karena ada wajib pajak yang tidak tertib membayar pajak, adanya wajib pajak yang tidak melaporkan omzet yang sebenarnya, kurangnya hunian restoran dan kurangnya pengadaan kegiatan-kegiatan tertentu di Kabupaten Kolaka yang bisa menarik perhatian banyak orang.

\section{Efektivitas Pajak Hotel Melati dan Pajak Restoran di Kabupaten Kolaka}

Dilihat dari sisi efektivitas pajak hotel melati selama tahun 2017 hingga 2019 efektivitas pajak hotel melati menunjukkan fluktuasi. Pada tahun 2017 dan 2018 pencapaian efektivitas untuk realisasinya masih belum mencapai target dimana persentasi masih menunjukkan dibawah 100\%. Pencapaian efektivitas yang belum efektif dikarenakan pendapatan dari hotel melati menurun yang diakibatkan oleh adanya wajib pajak yang belum membayar ataupun menunda kewajibannya. Namun pada tahun 2019 pencapaian efektivitas mengalami peningkatan dengan kriteria sangat efektif, hal ini disebabkan pada tahun tahun 2019 mulai diberlakukannya pemasangan alat tapping box. Meskpun nilai rasio efektivitas menunjukkan $>100 \%$ atau melebihi target yang telah ditetapkan patut dipertahankan dan ditingkatkan lagi dengan cara Badan Pendapatan Daerah Kabupaten Kolaka lebih giat lagi dalam memungut pajak hotel melati, serta mengevaluasi kembali apakah target yang telah ditetapkan sesuai dengan potensi yang sebenarnya.

Sedangkan berdasarkan hasil olahan data diatas dapat dilihat bahwa pencapaian persentase efektivitas pajak restoran dari tahun 2017-2019 tingkat efektivitas setiap tahunnya meningkat. Pada tahun 2017 dan tahun 2018 pencapaian efektivitas pajak restoran untuk realisasinya masih belum mencapai target dimana persentase masih menunjukkan dibawah 100\% dimana pada tahun 2017 dan 2018 pencapaian efektivitas yang belum sangat efektif karena pendapatan dari pajak restoran tidak mencapai targetnya yang diakibatkan oleh semakin menurunnya wajib pajak yang dapat melunasi kewajibannya tepat waktu. Namun pada tahun 2019 terjadi peningkatan, ini merupakan kinerja yang sangat baik karena perolehan pajak restoran sudah melebihi dari target yang telah ditetapkan. Kenaikan tersebut disebabkan Pemerintah Daerah Kabupaten Kolaka mulai memberlakukan pemasangan alat tapping box pada bulan Oktober 2019. Semakin tinggi tingkat efektivitas pajak, semakin efektif tingkat pelaksanaan pemungutan pajak. Pelaksanaan pemungutan pajak oleh Pemerintah Kabupaten Kolaka yang dalam hal ini 
dilakukan oleh Badan Pendapatan Daerah Kabupaten Kolaka, telah dilakukan sesuai dengan ketetapan Undang-Undang dan Peraturan Daerah yang berlaku.

\section{Kesimpulan}

\section{KESIMPULAN DAN SARAN}

Berdasarkan uraian pembahasan dan analisis dari hasil penelitian, maka dapat ditarik kesimpulan sebagai berikut:

1. Dari hasil analisis kontribusi pajak hotel dan pajak restoran untuk meningkatkan Pendapatan Asli Daerah (PAD) Kabupaten Kolaka tahun anggaran 2017-2019 masih tergolong sangat kurang. Dilihat secara keseluruhan selama tiga tahun berturut-turut, kontribusi pajak hotel dan pajak restoran pada peningkatan pendapatan asli daerah masih dibawah 10\% dikategorikan sangat kurang memberikan kontribusi. Sangat kurangnya kontribusi pajak hotel dan pajak restoran di kabupaten kolaka karena wajib pajak yang tidak tertib membayar pajak, adanya wajib pajak yang tidak melaporkan omzet yang sebenarnya, kurangnya hunian hotel melati dan restoran serta kurangnya pengadaan kegiatan-kegiatan tertentu di Kabupaten Kolaka yang bisa menarik perhatian banyak orang.

2. Tingkat efektivitas penerimaan pajak hotel melati berfluktuasi setiap tahunnya berbanding terbalik dengan pajak restoran di Kabupaten Kolaka tahun 2017-2019 yang dikur dengan rasio efektivitas meningkat setiap tahunnya. Hotel melati dan restoran yang efektivitas pajaknya belum mencapai $100 \%$ berarti realisasi penerimaan pajaknya belum mencapai targetnya. Sedangkan hotel melati dan restoran yang efektivitas pajaknya meningkat berarti hotel melati dan restoran tersebut realisasi penerimaan pajaknya melebihi targetnya. Semakin tinggi tingkat efektivitas pajak, semakin efektif tingkat pelaksanaan pemungutan pajak. Pelaksanaan pemungutan pajak oleh Pemerintah Kabupaten Kolaka yang dalam hal ini dilakukan oleh Badan Pendapatan Daerah Kabupaten Kolaka, telah dilakukan sesuai dengan ketetapan Undang-Undang dan Peraturan Daerah yang berlaku.

\section{Implikasi}

Berdasarkan kesimpulan diatas, menunjukkan bahwa semakin besar pendapatan realisasi pajak hotel melati dan pajak restoran maka semakin besar pula kontribusinya terhadap Pendapatan Asli Daerah. Begitu juga dengan tingkat efektivitas, semakin tinggi tingkat efektivitas pajak maka semakin efektif tingkat pelaksanaan pemungutan pajak. Pelaksanaan pemungutan pajak oleh Pemerintah Kabupaten Kolaka yang dalam hal ini dilakukan oleh Badan Pendapatan Daerah Kabupaten Kolaka, telah dilakukan sesuai dengan ketetapan Undang-Undang dan Peraturan Daerah yang berlaku.

\section{Keterbatasan}

Penelitian ini memiliki beberapa keterbatasan antara lain sebagai berikut:

1. Objek pada penelitian ini adalah "Analisis Kontribusi Pajak Hotel Melati dan Pajak Restoran Untuk Meningkatkan Pendapatan Asli Daerah di Kabupaten Kolaka"

2. Ruang lingkup penelitian ini terbatas pada pemahaman Analisis Kontribusi Pajak Hotel Melati dan Pajak Restoran Untuk Meningkatkan Pendapatan Asli Daerah di Kabupaten Kolaka. Sumber rujukan data untuk penelitian ini adalah melihat trend tiga tahun terakhir yaitu tahun 2017-2019.

\section{Rekomendasi}

Berdasarkan hasil penelitian dan kesimpulan yang telah dikemukakan diatas, maka penulis mencoba memberikan saran sebagai berikut:

1. Bagi pihak Badan Pendapatan Daerah Kabupaten Kolaka sebaiknya Pemerintah Kabupaten Kolaka lebih memperhatikan perkembangan jumlah usaha hotel melati dan 
restoran diantaranya dengan mulai memberikan sosialisasi, himbauan dan teguran kepada wajib pajak yang enggan untuk membayar pajaknya lantaran masih sedikit omzet yang mereka terima. Hal ini karena usaha hotel melati dan restoran memiliki peranan atau potensi yang besar dalam Pendapatan Asli Daerah Kabupaten Kolaka.

2. Bagi peneliti selanjutnya diharapkan untuk mengembangkan objek kajian dalam penelitian ini dengan memperbesar ruang lingkup penelitian yang hanya terbatas pada pajak hotel melati dan pajak restoran.

\section{DAFTAR PUSTAKA}

BAPENDA. 2018. Laporan Target dan Realisasi Penerimaan Pajak Hotel dan Pajak Restoran Tahun 2016-2018. Pemeritah Kabupaten Kolaka

Edwar, Memah. 2013. Efektivitas dan Kontribusi Pajak Hotel dan Pajak Restoran Terhadap PAD Kota Manado. Jurnal Emba Vol.1. No. 3 Juni 2013, Hal. 871-881

Halim, Abdul. 2007. Akuntansi Keuangan daerah. Salemba Empat. Jakarta.

Republik Indonesia. Undang-Undang No. 28 Tahun 2009 Tentang Ketentuan Umum dan Tata Cara Perpajakan.

Republik Indonesia. Undang-Undang Nomor 29 Tahun 2009 Tentang Pajak Daerah dan Retribusi Daerah.

Republik Indonesia. Undang-Undang Nomor 33 Tahun 2004 Tentang Perimbangan Keuangan Antara Pemerintah Pusat dan Pemerintah Daerah

Siaahan, Mariot Pahala. 2013. Pajak Daerah dan Retribusi Daerah. Jakarta: Salemba Empat

Sumarsan, Thomas. 2010. Perpajakan Indonesia. Jakarta: PT. Indeks 